\title{
Correction: Characteristics of infective endocarditis in a cancer population
}

Grable C, Yusuf S, Song J, et al. Characteristics of infective endocarditis in a cancer population. Open Heart 2021;8:e01664. doi:10.1136/openhrt-2021-001664

Since the publication of this article, initials have been added to the following author names: Saamir A Hassan and Syed W Yusuf.

Open access This is an open access article distributed in accordance with the Creative Commons Attribution Non Commercial (CC BY-NC 4.0) license, which permits others to distribute, remix, adapt, build upon this work non-commercially, and license their derivative works on different terms, provided the original work is properly cited, appropriate credit is given, any changes made indicated, and the use is non-commercial. See: http://creativecommons.org/licenses/by-nc/4.0/.

C Author(s) (or their employer(s)) 2021. Re-use permitted under CC BY-NC. No commercial re-use. See rights and permissions. Published by BMJ.

Open Heart 2021;8:e001664corr1. doi:10.1136/openhrt-2021-001664corr1

A) Check for updates 